\title{
KERUKUNAN ANTARUMAT BERAGAMA DALAM PERSPEKTIF HUKUM PIDANA
}

\section{July Esther}

Fakultas Hukum, Universitas HKBP Nommensen

Medan, Sumatera Utara, Indonesia

julyestherfh@yahoo.com

\begin{abstract}
Religious diversity is often a challenge in harmony, there is still statically addressed (exclusive), has not led to a motion proactive in building unity among religious. Harmony among religious believers in the perspective of criminal law refers to one of the articles in the Code of Penal about setting Crimes Against Public Order, namely Article 156a, which is the rider with the Presidential Decree of the Republic of Indonesia Number 1/the 1965 on the Prevention of Abuse and / or blasphemy. Treatment of the perpetrators either individual or organization or belief is preceded procedural measures and stages of criminal sanctions for perpetrators of violations of Article 1 of the Republic of Indonesia Presidential Decree No. 1/the 1965 as the final sanction which wants peace.
\end{abstract}

Keywords: harmony, religious communities, the criminal law.

\section{PENDAHULUAN}

Kecenderungan konflik sosial bercorak agama di bumi nusantara ini sudah seharusnya menjadi peringatan keras untuk mengambil sikap. Tetapi tampaknya keseriusan mengurusi hal-hal yang lain sudah dianggap merupakan keputusan yang terbaik dibandingkan mengurusi kerukunan antarumat beragama, walaupun yang dimaksudkan dalam hal ini bahwa kerukunan antarumat beragama bukan segala-galanya bagi pembangunan. Maka pola yang diperlihatkan para pemangku kepentingan sengaja atau tidak sengaja telah menempat kerukunan antarumat beragama berada pada titik kerawanan sosial, yang dapat berdampak pada konflik sosial yang destruktif, mana kala orang-orang yang sudah dirasuki kepentingan egois memanfaatkan keadaan tersebut untuk kepentingannya yang sesaat. 
Anggapan bahwa hukum formal, seperti Kitab Undang-Undang Hukum Pidana, undang-undang, dan peraturan-peraturan lain, sudah cukup memadai dalam mengatur peri kehidupan antarumat beragama. Akta legal dalam bentuk hukum yang dikeluarkan dari pemerintah pusat sampai ke pemerintah daerah sudah merupakan ketentuan yang otomatis wajib ditaati seluruh warga meskipun hukum formal seperti itu masih memerlukan adaptasi di daerah, atau bahkan tidak lebih relevan lagi terhadap kebijakan-kebijakan di lapangan.

Benni E. Matindas dalam pengantar bukunya Negarakertagama: Kimia Kerukunan memberikan pendapatnya tentang hidup keagamaan. Menurut dia, konflik keagamaan kerap menjadi kenyataan yang bertentangan dengan kerukunan. Tujuan beragama menurut dia adalah untuk kerukunan dan kedamaian hidup manusia. Negara pun ada untuk, antara lain, kehidupan yang rukun dan damai. Dari sudut pandang agama, negara adalah instrumen yang dibuahkan dari peradaban umat beragama untuk memaksimalkan pencapaian tujuan beragama. Dengan demikian, seharusnya, dengan agama dan negara maka kerukunan dan kedamaian semakin teraih setinggi-tingginya. Tetapi kenyataan menunjuk sebaliknya. ${ }^{1}$

Agama hadir di tengah masyarakat sebagai pembawa perpecahan. Agama menjadi alasan paling kuat bagi disintegrasi negara. Beragama berarti keharusan untuk berseteru dengan kelompok lain di tengah masyarakat. Dimensi keabadian dalam beragama menjadikan kerukunan sebagai kemustahilan yang cenderung abadi. ${ }^{2}$

\section{RUMUSAN MASALAH}

Kerukunan antarumat beragama adalah pokok yang sedang dikaji. Kerukunan antarumat beragama kerap menjadi perhatian yang mana merebak menjadi kasus atau konflik yang terjadi di dalam masyarakat, dan

\footnotetext{
h. 5

${ }^{1}$ Benni E. Matindas, Negarakertagama: Kimia Kerukunan, (Jakarta:Bina Insani, 2002),

${ }^{2}$ Ibid.
} 
akhirnya berujung pada sebuah putusan pengadilan. Penelitian ini membatasi diri pada kajian kerukunan antarumat beragama dalam perspektif hukum pidana yakni dasar hukum, sanksi pidana, dan penerapan Kitab UndangUndang Hukum Pidana dalam penyelesaian kasus kerukunan antarumat beragama.

\section{METODE PENELITIAN}

Ciri khas ilmu hukum adalah sifatnya yang normatif 3 , berdasarkan karakter preskriptif maka penelitian ini merupakan suatu penelitian hukum ${ }^{4}$ Normatif dengan menggunakan pendekatan undang-undang dan pendekatan konseptual. Untuk mendapatkan perspektif dasar tentang pokok masalah yang dikaji maka perlu diadakan studi kepustakaan. Literatur-literatur yang representatif diteliti untuk menemukan referensi yang menjelaskan pokok bahasan.

\section{PEMBAHASAN}

Kata rukun berasal dari bahasa Arab: ruknun (rukun), atau dalam bentuk jamak, arkan, yang berarti asas atau dasar, Rukun Islam, misalnya berarti asas Islam, atau dasar agama Islam. ${ }^{5}$

Kamus Umum Bahasa Indonesia, susunan W.J.S. Poerwadarminta, kata rukun berbentuk nomina dan ajektiva. Dalam bentuk nomina ia berarti: (a) sesuatu yang harus dipenuhi untuk sahnya pekerjaan, seperti: tidak sah sembahyang yang tidak cukup syarat dan rukunnya; (b) asas, berarti: dasar, sendi: semuanya terlaksana dengan baik, tidak menyimpang dari rukunnya; rukun Islam: tiang utama dalam agama Islam. Dalam bentuk ajektiva ia berarti: (a) baik dan damai (tentang pertalian persahabatan, suami istri, tidak

\footnotetext{
3 Philipus M. Hadjon dan Tatiek Sri Djatmiati, Argumentasi Hukum, (Jogyakarta: Gadjah Mada University Press, 2005), h. 1.

${ }^{4}$ Peter Mahmud Marzuki, Penelitian Hukum, (Jakarta: Prenada Media, 2006), h. 26.

5 Departemen Agama RI, Kompilasi Peraturan Perundang-Undangan Kerukunan Hidup Umat Beragama, (Jakarta: Departemen Agama RI, 1997), h. 5-6.
} 
bertengkar); (b) bersatu hati, ragem; (c) perkumpulan yang berdasar tolongmenolong dan persahabatan. ${ }^{6}$

Victor I. Tanja dalam tulisannya "Anatomi Kerukunan Umat Beragama Di Indonesia: Sebuah Tinjauan Sosial Budaya" menjelaskan arti kata rukun sebagai pilar atau tiang utama dalam agama Islam sebagai tiang-tiang yang kokoh menopang bangunan Islam yang di dalamnya iman berlangsung dalam keadaan aman dan tertib. Orang berbicara tentang arkan al Islam pada aspek exoteris dan arkan al iman dalam aspek esoteris. ${ }^{7}$ Kata rukun dipakai sebagai kata terapan dalam agama untuk menjelaskan sebuah bangunan. Pilar-pilar pada bangunan tersebut berdiri kokoh untuk saling menopang bangunan hidup beriman. Tidak jauh dari gambaran tersebut umat beragama yang beraneka ragam juga menggambarkan Indonesia yang rukun oleh umat beragama yang berdiri sebagai pilar-pilar bangunan. Semua umat beragama dapat saling bergandengan tangan membuktikan ajaran keluhuran agamanya yang mampu berkorelasi dengan siapapun dalam kebhinekaan.

Pemahaman yang rancu sering terjadi, bahwa kerukunan akan selalu otomatis terjadi meskipun tanpa didahului dengan usaha dan niat yang kuat untuk menciptakan kerukunan. Kerukunan seolah-olah bersifat taken for ganted (terima bersih) tanpa ada niat-niat untuk menciptakannya. Persepsi yang menganggap bahwa kerukunan akan datang sendirinya sama artinya menempatkan kerukunan pada kualitas yang tidak dapat dipertanggungjawabkan atau murahan, sementara kerukunan menunjukkan hakikatnya yang dinamis. Dia terkait dengan situasi sosial, ekonomi, politik, budaya dan lain-lain. Maka di sini kerukunan menunjukkan kedudukannya yang sangat esensil dalam pembangunan kenegaraan, kebangsaan. Umat beragama mempunyai posisi yang strategis sebagai pilar-pilar yang menopang

6 W.J.S. Poerwadarminta, Kamus Umum Bahasa Indonesia (Edisi Ketiga), (Jakarta: Balai Pustaka, 2003), h. 991.

7 Victor Immanuel Tanja, “Anatomi Kerukunan Umat Beragama Di Indonesia: Sebuah Tinjauan Sosial Budaya" dalam Kerukunan Umat Beragama Pilar Kerukunan Berbangsa, peny. Weinata Sairin, (Jakarta: BPK Gunung Mulia, 2011), h. 41-42. 
bangunan kebangsaan Indonesia. Tidak mungkin lagi kerukunan disikapi seperti pada masa-masa lalu mengingat perubahan-perubahan global yang radikal pada saat ini. Karena itu, kata "kerukunan" menjadi kata kunci masuk ke dalam semua gagasan persatuan di tengah-tengah kemajemukan yang nyata. ${ }^{8}$

Hukum pidana bermakna jamak, dalam arti obyektif sering disebut jus poenale, meliputi:

1. Perintah dan larangan, yang atas pelanggarannya atau pengabaiannya telah ditetapkan sanksi terlebih dahulu oleh badanbadan Negara yang berwenang, peraturan-peraturan yang harus ditaati dan diindahkan oleh setiap orang;

2. Ketentuan-ketentuan yang menetapkan dengan cara apa atau alat apa dapat diadakan reaksi terhadap pelanggaran peraturanperaturan itu;

3. Kaidah-kaidah yang menentukan ruang lingkup berlakunya peraturan-peraturan itu pada waktu dan di wilayah Negara tertentu. ${ }^{9}$ Kitab Undang-Undang Hukum Pidana sebagai hukum pidana materiil memiliki fungsi hukum pidana sebagai hukum publik sebab mengatur hubungan antara individu dengan negara dengan penjatuhan pidana dijatuhkan untuk mempertahankan kepentingan umum yang pelaksanaannya sepenuhnya di tangan pemerintah. Secara khusus melindungi 5 (lima) kepentingan hukum terhadap perbuatan yang tercela, kepentingan hukum yang berupa nyawa manusia, badan/tubuh manusia, kehormatan, dan kemerdekaan serta harta benda/harta kekayaan. Secara umum ialah mengatur kehidupan kemasyarakatan.

Kehidupan kemasyarakatan dalam bentuk kerukunan umat beragama terdapat di dalam ketentuan Buku II Bab V tentang Kejahatan Terhadap

8 Ampu Pargaulan Aritonang, "Pengembangan Kerukunan Antarumat Beragama Di Kota Tarakan", Disertasi, (Jakarta: Pascasarjana Sekolah Tinggi Teologi, 2014), h. 57.

9 H.A. Zainal Abidin Farid, Hukum Pidana I, (Jakarta: Sinar Grafika, 2007), h. 1. 
Ketertiban Umum Kitab Undang-Undang Hukum Pidana. Salah satu pasal dalam pengaturan Kejahatan Terhadap Ketertiban Umum tersebut terdapat satu pasal yang berkaitan dengan kerukunan umat beragama yakni Pasal 156a Kitab Undang-Undang Hukum Pidana yang merupakan pasal tambahan dengan Penetapan Presiden Republik Indonesia Nomor 1/PNPS Tahun 1965 tentang Pencegahan Penyalahgunaan dan/atau Penodaan Agama (Lembaran Negara Republik Indonesia Tahun 1965 Nomor 3, Tambahan Lembaran Negara Republik Indonesia Nomor 2726 (selanjutnya disingkat Penpres Nomor 1/PNPS Tahun 1965). Pasal 156a Kitab Undang-Undang Hukum Pidana menentukan:

Dipidana dengan pidana penjara selama-lamanya lima tahun barangsiapa dengan sengaja di muka umum mengeluarkan perasaan atau melakukan perbuatan:

a. Yang pada pokoknya bersifat permusuhan, penyalahgunaan atau penodaan terhadap suatu agama yang dianut di Indonesia;

b. Dengan maksud agar supaya orang tidak menganut agama apapun juga yang bersendikan Ke-Tuhanan Yang Maha Esa.

Unsur-unsur kejahatan yang dimaksud Pasal 156a Kitab Undang-Undang Hukum Pidana dapat dijelaskan sebagai berikut:

a. Subyek kejahatan: barangsiapa

b. Unsur-unsur:

- di muka umum;

- mengeluarkan perasaan atau melakukan perbuatan;

- perasaan atau perbuatan yang bersifat permusuhan, penyalahgunaan atau penodaan terhadap suatu agama;

- suatu agama yang dianut di Indonesia;

- dengan maksud supaya orang tidak menganut agama apapun juga yang bersendikan Ke-Tuhanan Yang Maha Esa. 
c. Stelsel Pemidanaan: Tidak bersifat komulatif, alternatif maupun alternatif dan/atau komulatif namun bersifat tunggal yakni dipidana dengan pidana penjara selama-lamanya lima tahun.

Unsur-unsur Pasal 156a Kitab Undang-Undang Hukum Pidana tersebut merupakan delik formil yang perumusan deliknya menekankan sikap tindak atau perikelakuan yang dilarang tanpa merumuskan akibatnya, yakni suatu perbuatan pidana yang sudah dilakukan dan perbuatan itu benar-benar melanggar ketentuan yang dirumuskan dalam pasal undang-undang yang bersangkutan. Perbuatan yang dimaksud adalah bersifat permusuhan, penyalahgunaan atau penodaan terhadap suatu agama yang dianut di Indonesia agar supaya orang tidak menganut agama apapun juga yang bersendikan Ke-Tuhanan Yang Maha Esa.

Mengeluarkan perasaan atau melakukan perbuatan sebagaimana dimaksud Pasal 156a Kitab Undang-Undang Hukum Pidana tidak menekankan pada akibat perbuatan yang bersifat permusuhan, penyalahgunaan atau penodaan terhadap suatu agama yang dianut di Indonesia, namun menekankan pada perbuatan yang bersifat permusuhan, penyalahgunaan atau penodaan terhadap suatu agama yang dianut di Indonesia itu sudah selesai dilakukan dan dengan maksud supaya orang tidak menganut agama apapun juga yang bersendikan KeTuhanan Yang Maha Esa.

Rumusan formil dalam Pasal 156a Kitab Undang-Undang Hukum Pidana dimaksudkan tidak perlu diselidiki terlebih dahulu perasaan atau perbuatan yang bersifat permusuhan, penyalahgunaan atau penodaan terhadap suatu agama mempunyai dasar-dasar yang benar ataukah tidak, juga tidak perlu diselidiki sifat permusuhan, penyalahgunaan atau penodaan terhadap suatu agama tersebut benar-benar berpengaruh kepada khalayak ramai sehingga seseorang tidak menganut agama apapun juga yang bersendikan Ke-Tuhanan Yang Maha Esa. Syarat yang penting dalam pasal ini adalah bahwa perbuatan 
itu dilakukan di muka umum, tidak perlu harus di pinggir jalan, akan tetapi di tempat yang dapat dilihat dan dikunjungi oleh orang banyak.

Mengacu pada unsur kejahatan Pasal 156a Kitab Undang-Undang Hukum Pidana yakni dengan maksud supaya orang tidak menganut agama apapun juga yang bersendikan Ke-Tuhanan Yang Maha Esa, maka orang yang melakukan pelanggaran pasal ini harus memiliki niat di dalam hatinya yang sengaja membuat orang lain tidak menganut agama apapun juga yang bersendikan Ke-Tuhanan Yang Maha Esa. Kesengajaan dengan maksud merupakan unsur subyektif yang ada di dalam diri pelaku dengan keyakinan bahwa perbuatannya harus terwujud sesuai dengan yang dikehendakinya.

Kesengajaan dengan maksud inilah sebagai salah satu dasar pemberat penjatuhan sanksi pidana bagi pelaku kejahatan Pasal 156a Kitab UndangUndang Hukum Pidana. Maksud yang terdapat di dalam hati si pelaku harus terwujud dengan melakukan perbuatan yang bersifat permusuhan, penyalahgunaan atau penodaan terhadap suatu agama sehingga ancaman pidana bagi si pelaku adalah bersifat tunggal yakni pidana penjara selamalamanya lima tahun. Sanksi pidana yang dijatuhkan oleh hakim satu-satunya adalah jenis pidana penjara tidak ada pilihan jenis pidana yang lain.

Beratnya sanksi pidana yang diancamkan bagi pelaku kejahatan Pasal 156a Kitab Undang-Undang Hukum Pidana merupakan implementasi dari amanah Pasal 29 ayat 1 dan 2 Undang-Undang Dasar 1945 yang menjelaskan bahwa Negara Indonesia berdasar atas Ketuhanan Yang Maha Esa dan negara menjamin kemerdekaan tiap-tiap penduduk untuk memeluk agamanya masing-masing dan untuk beribadat menurut agamanya dan kepercayaannya itu. Hal ini membuktikan bahwa Indonesia adalah negara yang beragama bukan negara yang tidak beragama (atheis) meskipun dalam Pasal 29 ayat 2 Undang-Undang Dasar 1945 tidak menjelaskan jenis agama dan kepercayaan yang dijamin oleh Negara Indonesia bagi para pemeluk agama dan kepercayaan untuk beribadah. 
Ketentuan Pasal 156a Kitab Undang-Undang Hukum Pidana ini dikenal dengan Pasal Penodaan Agama yang telah mengalami sidang uji materiil di Mahkamah Konstitusi Nomor 84/PUU-X/2012 dengan pokok perkara pengujian Pasal 156a Kitab Undang-Undang Hukum Pidana dan Pasal 4 Penetapan Presiden Republik Indonesia Nomor 1/PNPS Tahun 1965 tentang Pencegahan Penyalahgunaan dan/atau Penodaan Agama. Pasal Penodaan Agama ini diinterpretasikan sebagai ketentuan yang mengekang kebebasan beragama, namun dari rumusan pasal yang terurai dalam unsur-unsur kejahatan penodaan agama tidak bermaksud demikian melainkan untuk memberikan rambu-rambu terjadinya pelanggaran kebebasan umat beragama.

Penambahan Pasal 156a dalam Kitab Undang-Undang Hukum Pidana bermaksud menekankan perbuatan seseorang yang mengeluarkan perasaan atau melakukan perbuatan sesuai rumusan pasal telah melanggar ketertiban umum. Ketertiban umum yang dimaksud adalah dalam penafsiran luas tidak membatasi lingkup dan makna ketertiban umum pada ketentuan pasal di atas, namun meliputi segala nilai dan prinsip-prinsip hukum yang hidup dan tumbuh dalam masyarakat serta nilai-nilai kepatutan dan prinsip-prinsip keadilan umum.

Pemberlakuan rumusan kejahatan Pasal 156a Kitab Undang-Undang Hukum Pidana merupakan penegasan ketentuan Pasal 1 Penpres Nomor 1/PNPS Tahun 1965, yang menentukan

Setiap orang dilarang dengan sengaja di muka umum menceritakan, menganjurkan atau mengusahakan dukungan umum, untuk melakukan penafsiran tentang sesuatu agama yang dianut di Indonesia atau melakukan kegiatan-kegiatan keagamaan yang menyerupai kegiatankegiatan keagamaan dari agama itu, penafsiran dan kegiatan mana menyimpang dari pokok-pokok ajaran agama itu.

Pasal 1 tersebut memuat norma larangan bagi setiap orang untuk melakukan penafsiran dan kegiatan yang menyimpang dari pokok-pokok ajaran agama. 
Larangan tersebut tidak serta merta langsung memberikan sanksi pidana bagi pelaku yang melakukannya namun dalam Pasal 2 dan Pasal 3 berikutnya ditentukan tahapan-tahapan pemberian sanksi pidana.

Tahapan-tahapan pemberian sanksi pidana bagi pelaku pelanggaran Pasal 1 Penpres Nomor 1/PNPS Tahun 1965 tersebut adalah sebagai berikut:

1. Tahap pertama,

- Pemberian perintah dan peringatan keras terhadap orang untuk menghentikan perbuatan dalam suatu surat keputusan bersama Menteri Agama, Jaksa Agung, dan Menteri Dalam Negeri atau;

- Pembubaran organisasi dan menyatakan organisasi atau aliran tersebut sebagai organisasi/aliran terlarang oleh Presiden Republik Indonesia setelah mendapat pertimbangan dari Menteri Agama, Jaksa Agung, dan Menteri Dalam Negeri terhadap organisasi atau suatu aliran kepercayaan.

2. Tahap kedua, penjatuhan sanksi pidana penjara selama-lamanya lima tahun terhadap orang, organisasi atau aliran kepercayaan yang masih terus melanggar ketentuan Pasal 1.

Berdasarkan tahapan-tahapan tersebut tampak penanganan hukum yang berbeda bagi pelaku pelanggaran Pasal 1 Penpres Nomor 1/PNPS Tahun 1965 yang dilakukan oleh orang perseorangan dengan pelanggaran yang dilakukan oleh organisasi atau aliran kepercayaan. Penanganan terhadap pelaku baik orang perseorangan maupun organisasi atau aliran kepercayaan didahului tindakan tata tertib. Tindakan tata tertib dikenakan kepada pelaku mendahului pemberian sanksi pidana merupakan perwujudan dari fungsi hukum pidana sebagai ultimum remedium yakni pidana adalah sanksi terakhir yang diberikan bukan sebagai sanksi yang utama dan terutama.

Tahapan pemberian sanksi pidana bagi pelaku pelanggaran Pasal 1 Penpres Nomor 1/PNPS Tahun 1965 sebagai sanksi terakhir menurut peneliti adalah mengedepankan tujuan hukum ialah mengatur pergaulan hidup secara damai, hukum menghendaki perdamaian. Perdamaian di antara manusia 
dipertahankan oleh hukum dengan melindungi kepentingan-kepentingan manusia yang tertentu, kehormatan, kemerdekaan, jiwa, harta benda terhadap yang merugikannya. Hukum mempertahankan perdamaian dengan menimbang kepentingan yang bertentangan dan mengadakan keseimbangan. 10

Perdamaian di antara manusia akan menciptakan kerukunan umat beragama karena agama adalah hubungan antara Tuhan dan manusia yang membawa juga kewajiban untuk menuruti kehendak Tuhan. Agama memperoleh sifat kesusilaan keagamaan pada mana manusia dalam batinnya merasa terikat, berdasarkan hubungannya dengan Tuhan. ${ }^{11}$

Keberadaan Pasal 156a Kitab Undang-Undang Hukum Pidana dan Penpres Nomor 1/PNPS Tahun 1965 sangat membantu ketertiban hidup beragama. Hukum memberi andil dalam penegakan ketertiban. Konsekuensikonsekuensi yang diisyaratkan dalam hokum tersebut member shock terapy bagi individu untuk tidak sembarangan menyalahgunakan kebebasannya untuk mengganggu orang lain.

Pemerintah dengan peraturan yang dikeluarkannya dapat ditaati oleh umat beragama tetapi tidak dengan kekuasaan yang tanpa batas, sebab kekuasaan yang ada padanya berasal dari rakyat (umat beragama). Maka kekuasaan itu dikelola dengan baik untuk menempatkan umat dengan kemanusiaan yang bermartabat, bukan umat yang kehilangan martabat karena kekuasaan yang salah dijalankan atau dikelola.

\section{PENUTUP}

\section{kesimpulan}

Ketentuan Pasal 156a Kitab Undang-Undang Hukum Pidana dan Penpres Nomor 1/PNPS Tahun 1965 masih tetap berlaku sebagai dasar hukum penanganan dan penyelesaian hukum kejahatan terhadap agama dan

${ }^{10}$ L.J. van Apeldoorn, Pengantar Ilmu Hukum, (Jakarta: Pradnya Paramita, Cetakan Keduapuluhsembilan), h. 10-11.

${ }^{11}$ Ibid. 
kepercayaan yang dilakukan oleh orang perseorangan maupun oleh organisasi atau aliran kepercayaan. Tindakan tata tertib yang dikenakan kepada pelaku mendahului pemberian sanksi pidana berupa pidana penjara merupakan perwujudan dari fungsi hukum pidana sebagai ultimum remedium yakni pidana adalah sanksi terakhir yang diberikan bukan sebagai sanksi yang utama dan terutama.

\section{Saran}

Masyarakat harus bijak dalam menyikapi perbedaan terhadap agama yang ada di Indonesia, sebagai bentuk pengamalan Pancasila sebagai falsafah hidup berbangsa dan bernegara di Indonesia, sehingga penegak hukum dapat menjalankan fungsinya secara independen dan mencapai tujuan hukum yakni kemanfaatan, keadilan dan kepastian hukum.

\section{DAFTAR PUSTAKA}

Apeldoorn, L.J. van. Pengantar Ilmu Hukum, Cetakan Keduapuluhsembilan. Jakarta: Pradnya Paramita, 2001.

Anwar, Yesmil dan Adang. Pembaharuan Hukum Pidana: Reformasi Hukum Pidana. Jakarta: Grasindo, 2008.

Arief, Barda Nawawi. Beberapa Aspek Kebijakan Penegakan dan Pengembangan Hukum Pidana. Bandung: Citra Aditya Bakti, 1998.

Aritonang, Ampu Pargaulan. "Pengembangan Kerukunan Antarumat Beragama Di Kota Tarakan". Disertasi. Jakarta: Pascasarjana Sekolah Tinggi Teologi, 2014.

Azra, Azyumardi. Kerukunan Umat Beragama Pilar Utama Kerukunan Berbangsa. Jakarta: BPK Gunung Mulia, 2011.

Departemen Agama RI. Bingkai Teologi Kerukunan Hidup Umat Beragama Menurut Pandangan (Kristen) Protestan. Jakarta: Depag RI, 1997. Kompilasi Peraturan Perundang-Undangan Kerukunan Hidup Umat Beragama. Jakarta: Departemen Agama RI, 1997.

Farid, H.A. Zainal Abidin. Hukum Pidana I. Jakarta: Sinar Grafika, 2007.

Fatah, Rohadi Abdul. "Upaya Mewujudkan Kerukunan Antarumat Beragama." Dalam Kerukunan Umat Beragama Dalam Sorotan: Refleksi dan Evaluasi 10 (sepuluh) Tahun Kebijakan dan Program Pusat Kerukunan Umat Beragama, peny. Abdurrahman Mas'ud dkk. Jakarta: Kementerian Agama RI, 2011. 
Hadjon, Philipus M dan Tatiek Sri Djatmiati. Argumentasi Hukum. Jogyakarta: Gadjah Mada University Press, 2005.

Marzuki, Peter Mahmud. Penelitian Hukum. Jakarta: Prenada Media, 2006.

Matindas, Benni E. Negarakertagama: Kimia Kerukunan. Jakarta: Bina Insani, 2002.

Poerwadarminta, W.J.S. Kamus Umum Bahasa Indonesia (Edisi Ketiga). Jakarta: Balai Pustaka, 2003.

Tanja, Victor Immanuel. "Anatomi Kerukunan Umat Beragama Di Indonesia: Sebuah Tinjauan Sosial Budaya." Dalam Kerukunan Umat Beragama Pilar Kerukunan Berbangsa, peny. Weinata Sairin. Jakarta: BPK Gunung Mulia, 2011. 